\title{
Public Perception Survey Study on Air Quality Issues in Wuhan, China
}

\author{
Haiying Liu ${ }^{1 *}$, Mike Kobernus ${ }^{1}$, Hong Liu ${ }^{2}$ \\ ${ }^{1}$ Department of Environmental Impacts and Sustainability, Norwegian Institute for Air Research (NILU), Kjeller, Norway \\ ${ }^{2}$ Hubei Environmental Monitoring Centre Station (HEMC), Wuhan, China \\ Email: ^Hai-Ying.Liu@nilu.no, Mike.Kobernus@nilu.no, liuhong0903@aliyun.com
}

How to cite this paper: Liu, H.Y., Kobernus, M. and Liu, H. (2017) Public Perception Survey Study on Air Quality Issues in Wuhan, China. Journal of Environmental Protection, 8, 1194-1218.

https://doi.org/10.4236/jep.2017.810075

Received: August 28, 2017

Accepted: September 23, 2017

Published: September 26, 2017

Copyright $\odot 2017$ by authors and Scientific Research Publishing Inc. This work is licensed under the Creative Commons Attribution International License (CC BY 4.0).

http://creativecommons.org/licenses/by/4.0/

\begin{abstract}
In 2013, a survey on air quality (AQ) was conducted in Wuhan, China. The aim was to investigate public awareness of air pollution, and its epidemiological effect. This survey targeted both suburban and central city regions of $\mathrm{Wu}-$ han city, between August and December of 2013, where it engaged 1225 participants. Approximately 65\% perceived AQ in Wuhan to be "bad". Over 95\% recognized a causal association between air pollution and human health. About $65 \%$ were unaware of any action taken by the government to mitigate the air pollution situation. $84 \%$ indicated that the government should shut down highly polluting enterprises, while $95 \%$ expressed willingness to reduce private use of vehicles if required. The results demonstrate that the citizens of Wuhan are concerned about air pollution issues, and agree that improving $\mathrm{AQ}$ is the obligation of all citizens. Further, they called for concrete actions to improve AQ. The survey emphasized the need for better education and more activities to raise environmental awareness. The innovative aspects of this survey were the exploration of participants' perceptions of $A Q$ issues and the survey results may influence local government to impose stricter regulations, and to develop more effective programs involving citizens.
\end{abstract}

\section{Keywords}

Air Quality, Environmental Awareness, Human Health, Public Engagement, Public Perception

\section{Introduction}

Worldwide, air pollution represents the greatest environmental risk to human health. According to the World Health Organization (WHO), $11 \%$ of deaths were caused by air pollution around world in 2012 [1]. In China, air pollution is a severe problem and has increasingly become a major public health hazard [2] 
[3] [4] despite efforts to control it [5] [6]. For instance, high levels of smog and haze can often be encountered in many cities across China [2] [7].

In order to provide cost-effective control measures to improve air quality $(\mathrm{AQ})$, China has sought inspiration and support from European legislation and policy experiences when designing its environmental policies, in order to benefit from foreign experience, proven methodologies and state-of-the-art equipment. One of these proven tests was the EU-China Environmental Governance Programme (EU-China EGP) project, Hubei-AQ.info (Hubei AQ information and early warning system), launched in 2012 [8]. The Hubei-AQ.info project had a general aim to establish an integrated AQ information and early warning system for nine cities in Hubei province, providing AQ information to the public based on the assessment of public demand. One of the expected results of the project was to increase public awareness of $\mathrm{AQ}$, and enhance the public's understanding of environmental information. Currently, AQ information is presented to the public via a daily AQ Index (AQI). However, the links among AQI, concentration levels and health impacts are not widely understood by the public. Therefore, it is important to recognize how local residents perceive and understand air pollution and its potential impact on human health. For this reason, a questionnaire was designed and distributed amongst a representative number of the inhabitants of Wuhan in order to determine their level of understanding of AQ information, and the relation between AQ and health. This initiative has provided information for data providers (e.g., Hubei Environmental Monitoring Centre Station (HEMC)), decision makers (local government) and data consumers (e.g., public). The survey results can now be used to support the design of a public AQ information web solution that will address public concerns. Such a solution should offer the possibility to not only access information, but also to send formal requests to the web administration. More effective communication between public and the information providers will result in a better public understanding of AQ.

Recently, several studies have explored attitudes and behaviors in response to air pollution in China [2] [9] [10] [11] [12] [13]. These include public knowledge and perception of air pollution and smog in the Jing-Jin-Ji region [9] and Ningbo [10], residents' perception of $A Q$, pollution sources, and air pollution control in Nanchang [2] [11], Shanghai [12] and Jinchuan [13], as well as a survey on perception of air pollution and its health effect in Wuyuan [13], etc. These surveys have found that respondents that are less satisfied with local AQ are more likely to note air pollution and rate it as a serious local problem [12]. However, public opinion tends to deviate when faced with a public crisis [10]. Media are the main source for dissemination of air pollution information [10], and participants agreed that improving AQ is essential and should be the responsibility of both the government and individual citizens, but the number of people willing to change their behavior is small [13]. In addition, the difference in public perception of air pollution and their environmental awareness level is influenced by 
their environmental knowledge [2] [11], and is further influenced by their socio-economic status and family health experience, as well as proximity to the pollution source [16]. The findings from these studies suggest a need for the government to improve awareness of air pollution issues, and to implement $\mathrm{AQ}$ control measures more effectively [2] [13] [14].

Based on these studies in China and the objective of the Hubei-AQ.info project, in this paper we present an overview of the work performed in the $\mathrm{Wu}$ han AQ survey aimed to address the following questions: 1) How and to what extent does the public perceive AQ in their surroundings? 2) To what extent do participants understand the causes of air pollution and their related health effects? and 3) How and to what extent does individual education, economic, social and ecological conditions influence their perception on AQ issues? The AQ survey covered the following objectives: 1) ascertaining public perception on AQ in Wuhan, and awareness of the relationship between AQ and health, as well as sources of air pollution, understanding mitigation measures from the government and their attitude to the improvement of AQ; 2) engaging the public in the survey study, promoting participation in AQ-related environmental monitoring, and skill development; 3) improving communication between AQ information holders and the public; 4) exploring what environmental information is useful for the public; 5) providing recommendations on AQ-related information to the public; and 6) providing recommendations on AQ-related policies to decision and policy-makers. All of these objectives serve the main aim of raising environmental awareness, and determining public attitudes and perception for improving the environmental situation in Wuhan.

\section{Materials and Methods}

\subsection{Study Area}

The study was performed in Wuhan city $\left(30^{\circ} 35^{\prime} 35.16^{\prime \prime} \mathrm{N}\right.$ and $\left.114^{\circ} 18^{\prime} 19.41^{\prime \prime} \mathrm{E}\right)$. Wuhan is the capital of Hubei Province, and has a subtropical monsoon climate. In terms of population and area, Wuhan is the largest city in central China. It has a population of over 10 million and covers $8494.41 \mathrm{~km}^{2}$ [15]. At the time of writing, critical energy sources were coal, crude oil, coke, and electricity. This causes considerable pollution. In 2012, the total discharge of $\mathrm{SO}_{2}$ was 105,800 tons and the annual average of $\mathrm{SO}_{2}$ in ambient air was $0.030 \mathrm{mgm}^{-3}$ [16]. However, in addition to $\mathrm{SO}_{2}$, Wuhan also suffers from NOx and PM pollution. According to You (2014) [17], during the first six months of 2013, Wuhan managed only 47 attainment days, where pollution was within limits. All other days were over, due to $\mathrm{PM}_{2.5}$ pollution. The official monitoring results confirm that Wuhan has a serious $\mathrm{PM}_{2.5}$ pollution [17]. The project aimed to target a heterogeneous sample size with diverse opinions, different socio- and economic backgrounds. To accomplish this, the 13 districts selected in Wuhan, which include seven central districts (i.e., Jiang An, Jiang Han, Qiao Kou, Han Yang, Wu Chang, Hong Shan, Qing Shan) and six suburban districts (i.e., Dong Xi Hu, Cai Dian, Jiang Xia, Huang Po, Xin Zhou and Han Nan) (Figure 1) [18]. The suburb 


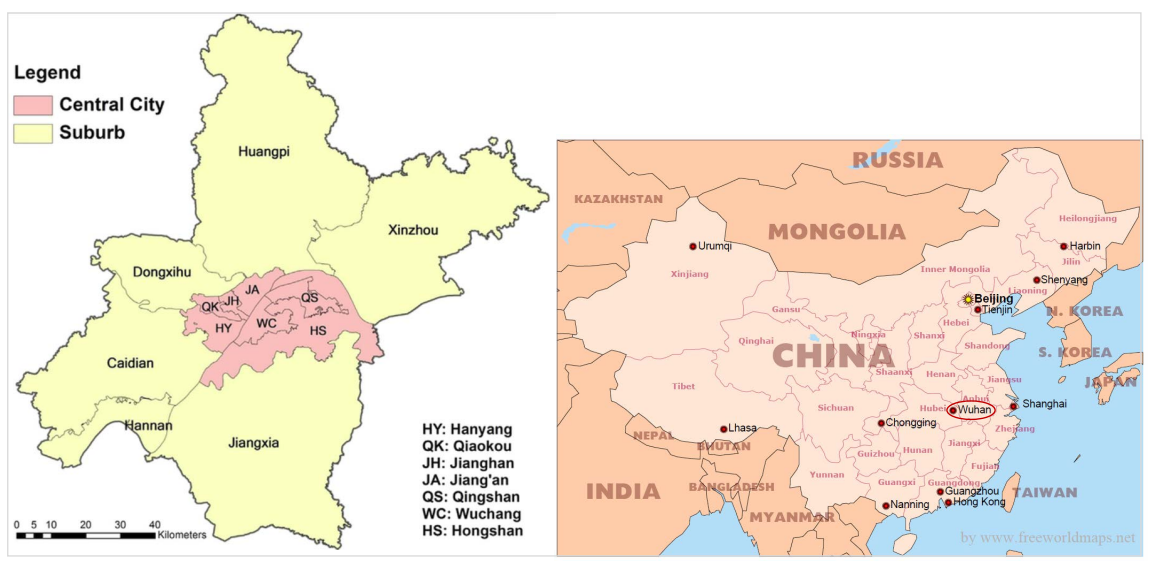

Figure 1. Location of Wuhan in China and the districts in Wuhan.

has a lower population than the city center. In terms of urban functions and land use characteristics, Jiang An, Jiang Han and Qiao Kou are the commercial and financial canter, Han Yang is the industrial center, and $\mathrm{Wu}$ Chang is the educational and cultural center. Hong Shan is the most populous of all the districts with $1,549,917$ population [19].

\subsection{Study Population, Sampling Strategy and Implementation Approach}

Our survey targeted at any public who might be interested in AQ issues. The survey was originally made in English, and then translated into Chinese for better public participation. The survey were distributed to the public, age from 14 to 75 , in each of the 13 districts via $Q Q$, microblog, e-mail, seminar, street and district questionnaire distribution.

We provided two methods to access the questionnaires: 1) Online: In order to facilitate participants to answer the questions, online access to the questionnaire was provided through the web-based project portal (http://www.hubei-aq.info); 2) Hard-copy: Printed copies were directly distributed on the street and in the districts of those who preferred to respond to the questionnaire on paper.

We implemented the survey through two types public participation approach: 1) Active (volunteered participation) and 2) Passive (motivated participation). The implementation period was five months, from August to December of 2013. Among the 1500 questionnaires submitted, 1225 were completed and included in the study analysis. Within 1225 valid questionnaires, 1000 were collected online by motivated approach (i.e., project paid 20RMB for each participant to answer questions), and 225 through volunteered online and offline participation.

\subsection{Questionnaire}

The AQ information questionnaire was designed as a "tool" for collecting and recording information and determining the basic attitudes/opinions of the public on AQ-related issues. It consisted of a series of questions, clear instructions, the alternative answers and the space for free answers. It was designed based on 
the current understanding of the cause-effect relationship (Driving force-Pressure-State-Exposure-Effect-Action (DPSEEA) framework) [18] of air pollution and its subsequent impact on the environment, ecosystems, society, economy and human health. It adopted a cross-sectional survey method, which consisted of nine parts. The first part related to the personal information of the participants. The second addressed the participants' basic understanding of AQ-related information. The next six parts consisted of questions regarding air pollution's driving force (D), pressure (P), state (S), exposure (E), effect (E) and action (A). In the last part, there was a field for final remarks and the participants' personal desires regarding AQ-related issues. The questions included in the survey required either single, or multiple-choice answers, with some having optional free text fields. The questionnaire took approximately $15-20$ minutes to answer all the questions.

\subsection{Quality Control}

The questionnaire was designed to take into account local conditions in Wuhan while complying with the research needs of practitioners from the Norwegian Institute for Air Research (NILU) and the Hubei Environmental Monitoring Centre Station (HEMC). HEMC practitioners collected the survey data and were trained by NILU in survey methods. Before launching the survey, HEMC's employees and their friends and family members were chosen to participate in a pre-launch test, to ensure the easy understanding of the questionnaire. The questionnaires received online and offline were organized and numbered, with unqualified questionnaires being removed. Double entry was performed by two persons in separate files and then crosschecked twice for data accuracy. A final verification step was then taken by double-checking the original questionnaire, if there was a data mismatch between the two entries.

\subsection{Statistical Analysis}

The survey was input and stored in a professional online survey platform, Sojump [20] and R Statistical Software was used for analysis. Demographic characteristics of participants, and their perception of AQ and health, were depicted with descriptive statistics. Multiple regression analysis was used to assess the associations between participants' knowledge and awareness level on AQ-related issues and their commonality/differences amongst participants' gender, age, education level, occupation, living district and area. Significance level was set at $p<0.05$

\section{Results}

\subsection{Participants Demographic Information}

Table 1 depicts the participants to the introductory questions. Among the 1225 participants, 46\% were male and 54\% female. Most were between 18 - 45 (76\%), had college-level education or higher (94\%), had not been/are not involved in 
Table 1. General demographic characteristics of the participants $(n=1225)$.

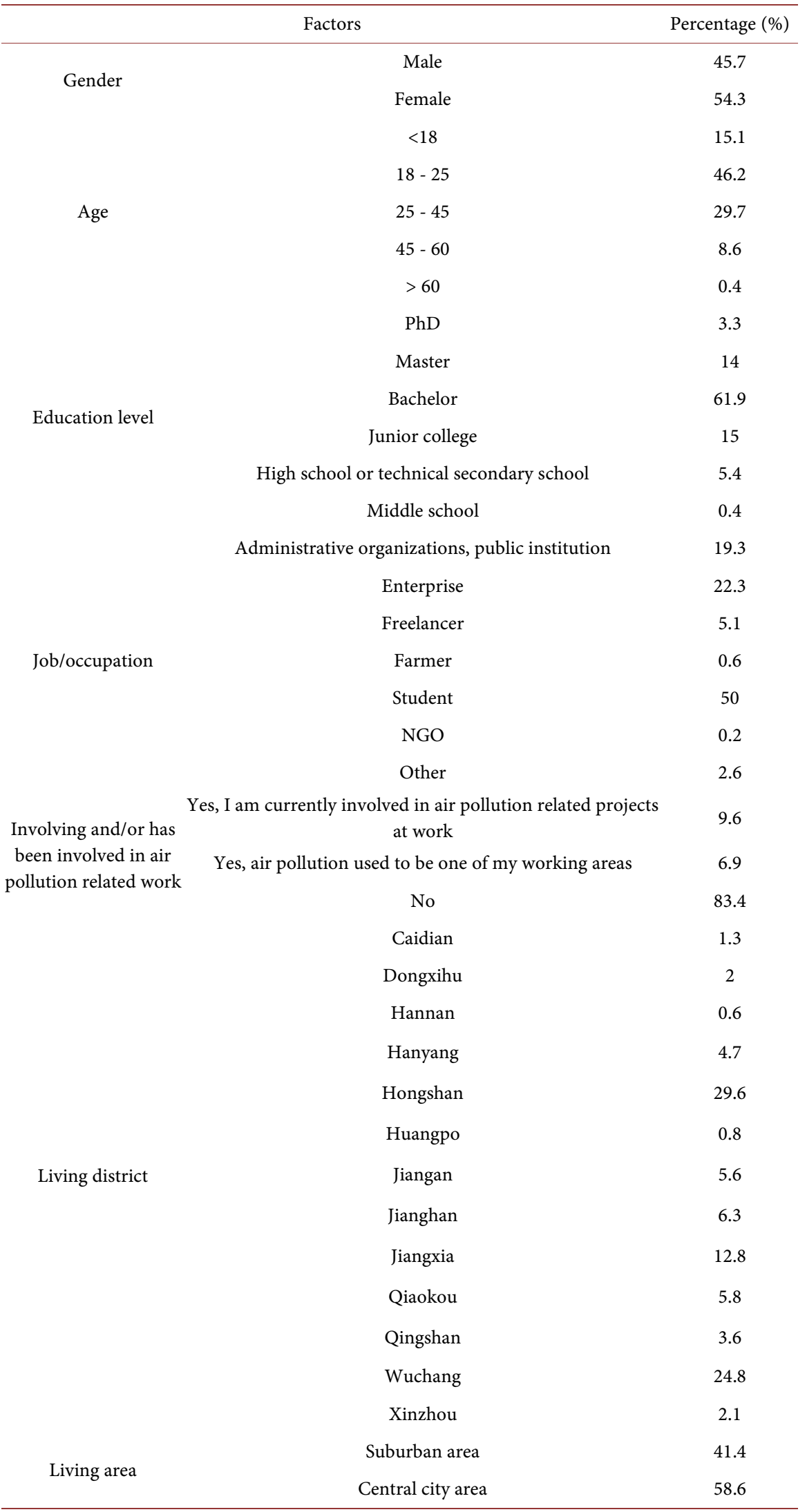


any air pollution related activities or work (83\%) and live in an central city area (69\%, Figure 1), e.g., Hong Shan (30\%) and Wu Chang (25\%). Almost half of participants were students, followed by participants employed either at various enterprises, or from administrative organizations and/or public institutions.

\subsection{Participants Basic Knowledge on Air Quality Issues}

Table 2 presents the results linking to the participants' basic understanding of AQ-related information. Nearly $96 \%$ knew what air pollution is. Around $94 \%$ did care about AQ issues in their surroundings. About $68 \%$ thought AQ was bad in Wuhan and $30 \%$ believed AQ in Wuhan to be moderate. Most concerned about $\mathrm{PM}_{2.5}$ (84\%), $\mathrm{SO}_{2}$ (57\%) and $\mathrm{HCHO}(42 \%)$ as the major air pollutants. $77 \%$ showed their interest in AQ information and $15 \%$ would like to learn more about it.

\subsection{Participants Perception on Air Quality-Driving Forces and Pressure}

With regard to the questions linking to the main driving forces and pressure for

Table 2. Participants' basic understanding of the air quality-related issues.

\begin{tabular}{|c|c|c|}
\hline \multicolumn{2}{|c|}{ Please answer the following questions } & \multirow{2}{*}{$\begin{array}{c}\text { Percentage (\%) } \\
96\end{array}$} \\
\hline & Yes & \\
\hline 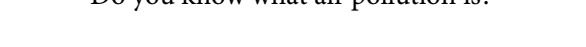 & No & 4 \\
\hline Do you care about the AQ issues in the area you & Yes & 94 \\
\hline \multirow[t]{2}{*}{ live, work or study? } & No & 6 \\
\hline & Good & 2 \\
\hline \multirow[t]{6}{*}{ Do you think the AQ in Wuhan is good or bad? } & Moderate & 30 \\
\hline & $\mathrm{Bad}$ & 68 \\
\hline & $\mathrm{PM}_{10}$ & 35 \\
\hline & $\mathrm{PM}_{2.5}$ & 84 \\
\hline & $\mathrm{SO}_{2}$ & 57 \\
\hline & $\mathrm{NO}_{2}$ & 36 \\
\hline \multirow{7}{*}{$\begin{array}{l}\text { What are the main air pollutants you are most } \\
\text { concerned? (multiple choice) }\end{array}$} & $\mathrm{CO}$ & 35 \\
\hline & $\mathrm{O}_{3}$ & 24 \\
\hline & $\mathrm{HCHO}$ & 42 \\
\hline & $\mathrm{Pb}$ & 29 \\
\hline & Other (e.g., dust) & 2 \\
\hline & I don't know & 0.4 \\
\hline & Yes & 77 \\
\hline \multirow[t]{2}{*}{$\begin{array}{l}\text { Are you interested in AQ information and do you } \\
\text { want to learn more about it? }\end{array}$} & No & 8 \\
\hline & I want to learn more & 15 \\
\hline
\end{tabular}


air pollution, most participants chose transportation needs (91\%), economic development (90\%), energy demand (66\%) and population increase $(65 \%)$ as the main driving forces (Figure 2), and believed that waste release/emissions (91\%), construction (77\%) and production (70\%) were the major human activities that put pressure on the environment (Figure 3 ).

\subsection{Participants Perception on Air Quality-State}

For the questions that can be linked to the state indicator on $A Q$, we can see (Table 3) that around $40 \%$ of participants knew about the AQI in China, with most of them accessing AQ information through websites, mobile phone software, TV and newspaper. While over $50 \%$ were not aware that there is a realtime AQ release system in Wuhan, $44 \%$ were aware, but had never or rarely visited it. Around $60 \%$ were interested in the information on air pollutant concentrations, AQ grade, and AQ forecast. More than $70 \%$ chose forecasts on environmental quality, meteorological conditions connected to air pollution, and forecast of AQ haze and visibility as the most demanded AQ services. Around

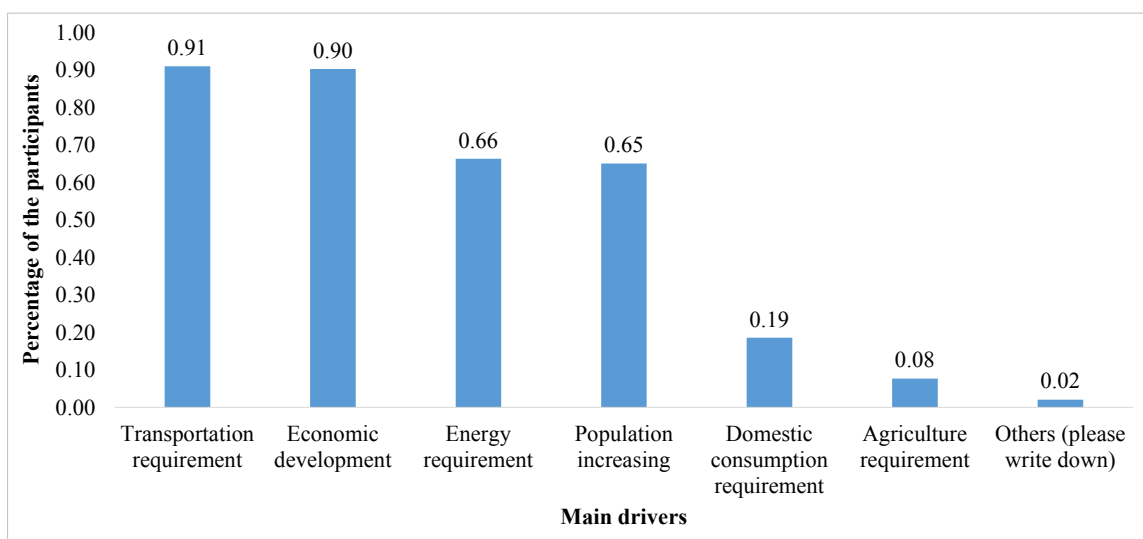

Figure 2. Participants' perception for the key driving forces of environmental pressures on air quality in Wuhan (multiple choice of the proposed answers).

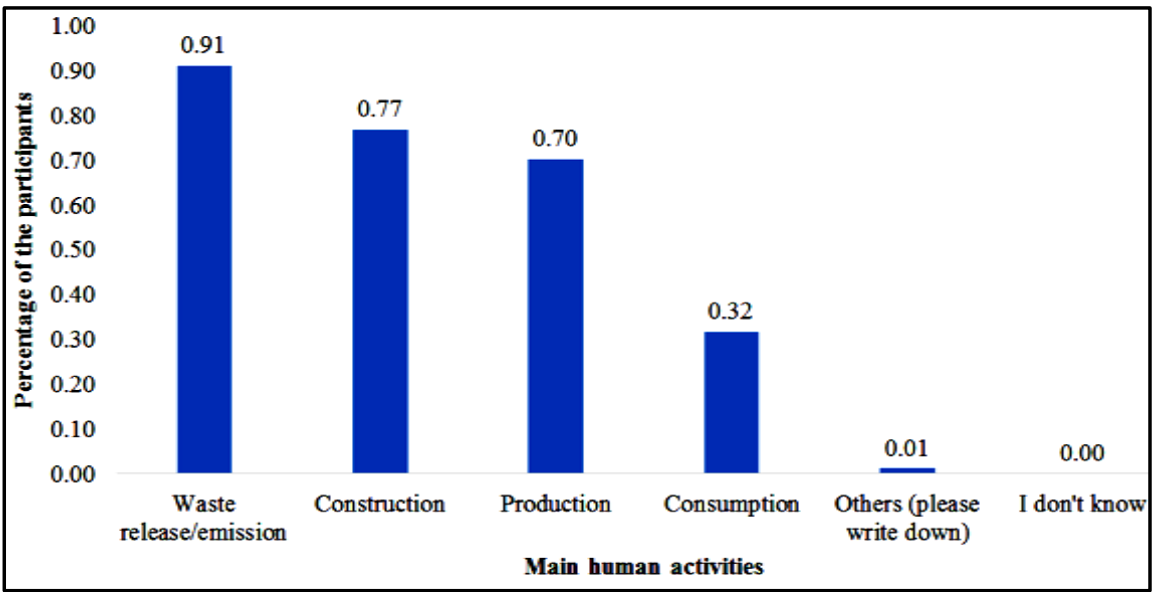

Figure 3. Participants' perception for the actual pressures (all sectors of economic activity) on the environment in Wuhan (multiple choice of the proposed answers). 
Table 3. Participants' general perception for air quality: State.

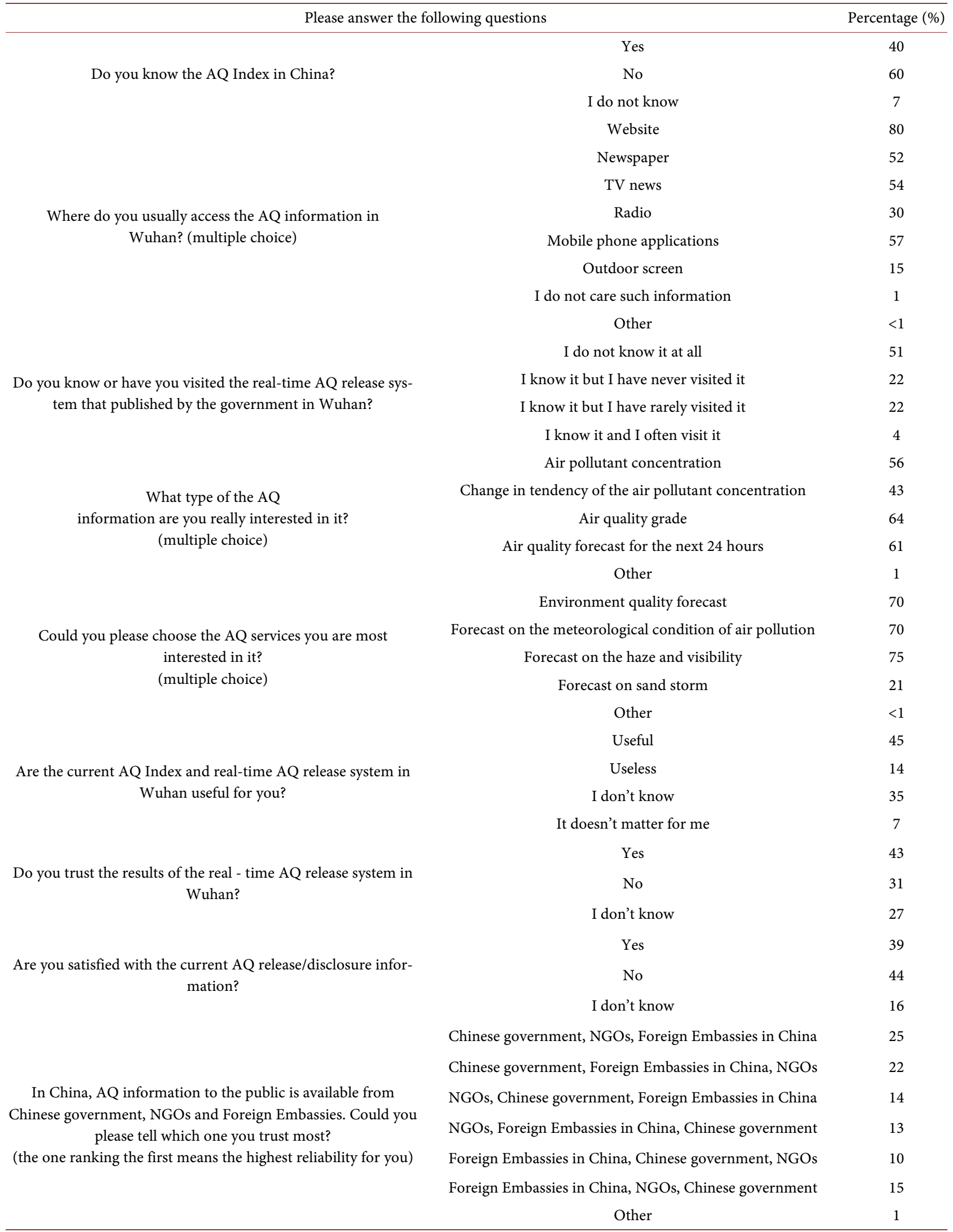


45\% thought the current AQI and real-time AQ information provide useful information for their daily life, but most were not satisfied with the quality of such information. $25 \%$ trust most the AQ information released by the Chinese government, followed by NGOs and foreign embassies in China, while around 15\% only trust the AQ information released by the Foreign Embassies (i.e., US Embassy), followed by NGOs and the Chinese government.

\subsection{Participants Perception on Air Quality-Exposure and Effect}

For the question linking to the exposure routes (i.e., questions linking to how people are exposed to toxic air pollutants that can pose health risks), approximately $77 \%$ of the participants knew that breathing polluted air was the most direct way to be exposed to air pollution. For other routes of exposure, $12 \%$ chose skin contact with contaminated soil, dust, or water, $8 \%$ chose drinking water contaminated by toxic air pollutants (Table 4).

For the questions linked to environmental health effects, $96 \%$ knew that air pollution can have negative effects on the environment, economy, society and health, and $85 \%$ felt uncomfortable or sick when they breathe polluted air (Table 4). Almost all the participants knew that exposure to toxic air pollutants can

Table 4. Participants' general perception for air quality: Exposure and Effect.

\begin{tabular}{|c|c|c|}
\hline \multicolumn{2}{|c|}{ Please answer the following questions } & $\begin{array}{l}\text { Percentage } \\
\quad(\%)\end{array}$ \\
\hline \multirow{5}{*}{$\begin{array}{l}\text { Do you know how people expose to the toxic air } \\
\text { pollutants that can pose health risks? } \\
\text { (multiple choice) }\end{array}$} & I don't know & 4 \\
\hline & Breathing contaminated air & 77 \\
\hline & $\begin{array}{l}\text { Drinking water contaminated by } \\
\text { toxic air pollutants }\end{array}$ & 8 \\
\hline & Eating contaminated food & 5 \\
\hline & $\begin{array}{l}\text { Touching contaminated soil, } \\
\text { dust, or water }\end{array}$ & 12 \\
\hline \multirow{6}{*}{$\begin{array}{l}\text { Do you know that air pollution can cause negative } \\
\text { effects on environment, economy, social and health? }\end{array}$} & Ingesting contaminated soil & 5 \\
\hline & Other & $<1$ \\
\hline & Yes & 96 \\
\hline & No & 3 \\
\hline & I don't know & 1 \\
\hline & Yes & 85 \\
\hline \multirow[t]{2}{*}{$\begin{array}{l}\text { Do you feel sick or uncomfortable when } \\
\text { air quality is bad? }\end{array}$} & No & 2 \\
\hline & Feeling is not obvious & 13 \\
\hline \multirow{5}{*}{$\begin{array}{l}\text { Could you please tell us which human organs can be } \\
\text { affected by air pollution? (multiple choice) }\end{array}$} & Pulmonary & 98 \\
\hline & Cardiac & 45 \\
\hline & Vascular & 47 \\
\hline & Neurological & 36 \\
\hline & Other & 3 \\
\hline
\end{tabular}


cause pulmonary disease, and around $45 \%$ knew that exposure to polluted air can cause cardiac and vascular disease as well (Table 4).

\subsection{General Perception on Air Quality-Actions}

When the participants were asked about their opinion on governmental actions and their individual actions toward improving AQ (Table 5), around $49 \%$ said that public transport (i.e., bus) was their major transportation mode. Only 7\% used private cars, and $2 \%$ used motorcycles. This may be influenced by the fact that most of the participants were students.

Nearly $65 \%$ used AQ information as a reference for their outdoor activities. Over $80 \%$ strongly opposed Chinese social development modes, i.e., developing economy first and protecting environment second. Most of the participants expressed their willingness to reduce air pollution through individual behavioral changes, e.g., thinking seriously before using a private car, using public transportation, reducing their energy consumption and switching to clean renewable energy sources at home, stop burning solid fuels, etc. It is very interesting to note that $65 \%$ were not aware of any actions that have been implemented in Wuhan to help reduce air pollution, or did not believe that any action had been implemented at all. Only $15 \%$ had air purifiers at home, while $40 \%$ planned to buy one. $45 \%$ did not plan to buy an air purifier. This result may also be influenced as many participants were students living in shared spaces.

Furthermore, several participants suggested various measures to improve AQ in Wuhan, such as resettling or closing enterprises with high pollution, high energy consumption and outdated production methods, and restricting the use of motor vehicles and increasing the use of environmentally-friendly vehicles. A few participants recommended that cleaning the road with water to remove the dust from construction activities, limiting private cars' driving time, and restricting the number of private cars purchased. Some participants called for strengthening the implementation of pollution discharge regulations, air pollution control and improving $\mathrm{AQ}$, closing all barbecue coal stands on the street throughout the city, and launching and implementing new pollution regulations for newly started high pollution projects.

\subsection{Final Remarks/Comments from the Participants}

Nearly $95 \%$ of the participants expressed their willingness to follow environmental contingency plans if the government required them to do so. $87 \%$ believed that they have attained new knowledge from our survey on air pollution. After our survey, these participants began paying attention to AQ-related information released from the government, and from other sources. Furthermore, they have learned personal/individual behaviors can have a positive/negative impact on $\mathrm{AQ}$ and health effects. In addition, these participants have learned that our Hubei-AQ project and local " $1+8$ " city cluster haze monitoring projects are taking measures on AQ in Wuhan, and strongly calling for more 
Table 5. Participants' general perception for air quality: Action.

\begin{tabular}{|c|c|c|}
\hline & Please answer the following questions & $\begin{array}{l}\text { Percentage } \\
\quad(\%)\end{array}$ \\
\hline \multirow{7}{*}{$\begin{array}{l}\text { What is/are your major } \\
\text { transportation mode(s) for your daily life? }\end{array}$} & Foot & 24 \\
\hline & Bicycle & 6 \\
\hline & Bus & 49 \\
\hline & Subway & 11 \\
\hline & Private car & 7 \\
\hline & Motorcycle & 2 \\
\hline & Other & 1 \\
\hline \multirow{2}{*}{$\begin{array}{l}\text { Will the ambient air conditions serve as } \\
\text { reference for your outdoor activities? }\end{array}$} & Yes & 65 \\
\hline & No & 35 \\
\hline \multirow{3}{*}{$\begin{array}{l}\text { Do you support Chinese traditional social } \\
\text { development mode-developing economy } \\
\text { first and protecting environment second? }\end{array}$} & Yes & 17 \\
\hline & No & 81 \\
\hline & I don't care & 2 \\
\hline \multirow{9}{*}{$\begin{array}{l}\text { Have you ever considered reducing air } \\
\text { pollution through any of the following } \\
\text { individual behavioral changes? (multiple } \\
\text { choice) }\end{array}$} & $\begin{array}{l}\text { Think seriously before using your car for an outdoor journey, and try best to } \\
\text { use public transportation }\end{array}$ & 78 \\
\hline & When doing the shopping or going to work, think about car sharing & 35 \\
\hline & Turn off your car engine while stationary & 27 \\
\hline & Maintain your car properly & 17 \\
\hline & Always try to reduce or slow down your speed when you drive & 12 \\
\hline & Buy green and efficient car & 49 \\
\hline & $\begin{array}{l}\text { Reducing your energy consumption at home or switching to clean } \\
\text { renewable energy sources, stop burning solid fuels }\end{array}$ & 63 \\
\hline & I have never considered to reduce air pollution through changing my own behavior & 3 \\
\hline & Other & 1 \\
\hline \multirow{3}{*}{$\begin{array}{l}\text { Are you aware of any of actions that have } \\
\text { been implemented in Wuhan to help } \\
\text { reducing the air pollution? }\end{array}$} & Yes & 32 \\
\hline & No & 65 \\
\hline & I don’t care & 3 \\
\hline \multirow{3}{*}{ Do you have air purifier at home? } & Yes & 15 \\
\hline & No, but plan to buy & 40 \\
\hline & No, do not plan to buy & 45 \\
\hline \multirow{5}{*}{$\begin{array}{l}\text { If the area you live requires the } \\
\text { environmental contingency plans, what kind } \\
\text { of policies or intervention measures do you } \\
\text { suggest the government to take or } \\
\text { implement? (multiple choice) }\end{array}$} & Close the highly polluting enterprises & 84 \\
\hline & Restrict the use of motor vehicles & 63 \\
\hline & Spray water to remove the street dust & 66 \\
\hline & I do not have any suggestion at all & 2 \\
\hline & Other & 2 \\
\hline $\begin{array}{l}\text { If the area you live requires the } \\
\text { environmental contingency plans, and the } \\
\text { government requires you to reduce the }\end{array}$ & Yes, I accept it & 95 \\
\hline $\begin{array}{l}\text { private car driving time, do you accept or } \\
\text { refer to follow? }\end{array}$ & No, I will not accept it & 5 \\
\hline
\end{tabular}


such environmental awareness raising activities to reach the wider public in Wuhan. Some of the participants also commented that the survey was easy to understand, but they hope that through this questionnaire more information will be available on the HEMC and/or Wuhan Environmental Protection Bureau (EPB) web regarding the local actions and real-time AQ reports.

\subsection{Difference of the Participants Perceptions toward Air Quality, Health Effects and Governmental Actions}

Results from a multivariate regression analysis of factors associated with the participants' knowledge and awareness level of AQ are presented in Table 6. Participants' perception towards AQ levels was found to be negatively associated ( $\beta$ $=-0.13, p=0.03)$ with the participants' living area. Participants were living in the central city area ranked AQ worse when compared to participants living in suburban area (Table 7). Farmers knew less about air pollution and its health effects when compared to other types of participants $(\beta=-0.24, p=0.03)$ (Table 8). Participants who were 25 - 45 years old were the most likely to have a high awareness level of government actions compared to other age groups $(\beta=0.297$, $p<0.0001)$, while those participants with middle school $(\beta=-0.51, \mathrm{p}=0.03)$ and high school $(\beta=-0.17, p=0.01)$ education and occupations as students ( $\beta=$ $-0.18, p<0.0001$ ) have a low awareness level of government actions (Table 9). Participants' willingness to change their behavior was found to be positively associated with gender $(\beta=0.04, p=0.002)$ and education $(\beta=0.13, p=0.03)$ (Table 10). Participants with age $25-45$ and occupation at public and govern mental organizations have a higher number of air purifiers at home, or were more willing to buy an air purifier compared to other age groups and occupations, while high school students have the lowest number of air purifiers at home or were not willing to buy an air purifier (Table 11).

\section{Discussion}

Currently, there are several AQ-related researches being conducted in China. Historically however, the results of such research have limited penetration into the public sphere, and the public are largely unaware of them. Furthermore, the literacy required to fully comprehend research results has not been formalized in China. In many countries, the relationship between health and AQ has been thoroughly studied and education on environmental health amongst university students is prevalent. A study conducted in the USA found that environmental health education in the community was conducive to forming good environmental health habits. These actions support environmental policies and participation in environmental health related research activities and will be especially useful in protecting public health by increasing the public's awareness of environmental protection [12]. Therefore, it is necessary to strengthen AQ knowledge and its potential effect on university students, the government, and relevant departments, in order to increase efforts in improving $\mathrm{AQ}$ in China. 
Table 6. Results from a multivariate regression analysis of factors related to the participants' knowledge and awareness level about air quality in Wuhan.

\begin{tabular}{|c|c|c|c|c|c|c|c|c|c|c|c|}
\hline \multirow{2}{*}{\multicolumn{2}{|c|}{ Factors }} & \multicolumn{2}{|c|}{$\begin{array}{l}\text { Perception } \\
\text { toward air } \\
\text { quality level }\end{array}$} & \multicolumn{2}{|c|}{$\begin{array}{c}\text { Knowledge } \\
\text { about air } \\
\text { pollution and its } \\
\text { heath effect }\end{array}$} & \multicolumn{2}{|c|}{$\begin{array}{c}\text { Awareness for } \\
\text { government } \\
\text { actions }\end{array}$} & \multicolumn{2}{|c|}{$\begin{array}{c}\text { Willingness to } \\
\text { change the } \\
\text { behaviors }\end{array}$} & \multicolumn{2}{|c|}{$\begin{array}{l}\text { Air purifier } \\
\text { needs at } \\
\text { home }\end{array}$} \\
\hline & & $\beta$ & $p$ value & $\beta$ & $p$ value & $\beta$ & $p$ value & $\beta$ & $p$ value & $\beta$ & $p$ value \\
\hline \multirow{2}{*}{ Gender } & Intercept & 1.69 & $<0.0001$ & 2.95 & $<0.0001$ & 2.28 & $<0.0001$ & 1.03 & $<0.0001$ & 1.73 & $<0.0001$ \\
\hline & Male & 0.02 & 0.78 & -0.03 & 0.10 & 0.01 & 0.78 & 0.04 & 0.002 & -0.08 & 0.06 \\
\hline \multirow{4}{*}{ Age } & $18-25$ & -0.01 & 0.94 & -0.02 & 0.26 & 0.02 & 0.60 & -0.01 & 0.82 & -0.09 & 0.12 \\
\hline & $25-45$ & 0.05 & 0.68 & 0.03 & 0.72 & 0.30 & $<0.0001$ & -0.01 & 0.54 & 0.40 & $<0.0001$ \\
\hline & $45-60$ & -0.05 & 0.75 & 0.00 & 0.96 & -0.01 & 0.85 & 0.02 & 0.77 & 0.18 & 0.05 \\
\hline & $>60$ & -0.62 & 0.27 & 0.05 & 0.68 & 0.13 & 0.67 & -0.05 & 0.64 & 0.36 & 0.36 \\
\hline \multirow{5}{*}{ Education } & $\begin{array}{l}\text { Middle } \\
\text { school }\end{array}$ & 0.10 & 0.81 & 0.06 & 0.67 & -0.51 & 0.03 & -0.04 & 0.66 & -0.33 & 0.30 \\
\hline & High school & 0.04 & 0.80 & -0.03 & 0.53 & -0.17 & 0.01 & 0.04 & 0.19 & -0.22 & 0.02 \\
\hline & Junior college & $e-0.09$ & 0.29 & -0.01 & 0.76 & -0.06 & 0.21 & 0.01 & 0.90 & -0.07 & 0.25 \\
\hline & Master & -0.09 & 0.38 & 0.03 & 0.28 & -0.03 & 0.58 & 0.03 & 0.13 & -0.02 & 0.83 \\
\hline & $\mathrm{PhD}$ & -0.41 & 0.14 & 0.06 & 0.63 & -0.06 & 0.69 & 0.13 & 0.03 & -0.23 & 0.27 \\
\hline \multirow{5}{*}{ Occupations } & Farmer & 0.03 & 0.97 & -0.24 & 0.03 & -0.25 & 0.21 & -0.04 & 0.45 & -0.43 & 0.10 \\
\hline & Freelancer & 0.14 & 0.31 & -0.04 & 0.39 & -0.11 & 0.15 & 0.01 & 0.96 & 0.00 & 0.96 \\
\hline & $\begin{array}{l}\text { Public or } \\
\text { governmental } \\
\text { organization }\end{array}$ & $1-0.04$ & 0.71 & 0.02 & 0.84 & 0.07 & 0.25 & 0.01 & 0.67 & 0.25 & 0.00 \\
\hline & Student & -0.01 & 0.93 & -0.02 & 0.96 & -0.18 & $<0.0001$ & 0.01 & 0.99 & -0.32 & $<0.0001$ \\
\hline & Other & -0.02 & 0.90 & -0.06 & 0.33 & -0.09 & 0.37 & -0.01 & 0.97 & 0.07 & 0.59 \\
\hline \multirow{12}{*}{$\begin{array}{l}\text { Living } \\
\text { district }\end{array}$} & Dongxihu & 0.35 & 0.27 & 0.13 & 0.17 & -0.27 & 0.12 & 0.04 & 0.53 & -0.22 & 0.35 \\
\hline & Hannan & 0.11 & 0.70 & -0.01 & 0.94 & -0.11 & 0.63 & 0.00 & 1.00 & -0.29 & 0.38 \\
\hline & Hanyang & 0.11 & 0.70 & 0.08 & 0.33 & -0.07 & 0.63 & 0.00 & 1.00 & -0.28 & 0.18 \\
\hline & Hongshan & -0.14 & 0.57 & 0.07 & 0.34 & -0.09 & 0.54 & 0.07 & 0.20 & -0.35 & 0.06 \\
\hline & Huangpo & 0.31 & 0.43 & 0.13 & 0.26 & -0.30 & 0.16 & 0.00 & 1.00 & -0.50 & 0.08 \\
\hline & Jiangan & 0.06 & 0.84 & 0.03 & 0.69 & -0.12 & 0.44 & 0.05 & 0.40 & -0.22 & 0.29 \\
\hline & Jianghan & 0.02 & 0.94 & 0.03 & 0.74 & -0.17 & 0.25 & 0.03 & 0.61 & -0.21 & 0.29 \\
\hline & Jiangxia & 0.17 & 0.51 & 0.08 & 0.31 & -0.14 & 0.24 & 0.05 & 0.41 & -0.33 & 0.08 \\
\hline & Qiaokou & -0.18 & 0.53 & 0.08 & 0.37 & -76.00 & 0.64 & 0.05 & 0.39 & -0.30 & 0.17 \\
\hline & Qingshan & 0.19 & 0.54 & -0.01 & 0.88 & -0.11 & 0.51 & 0.03 & 0.65 & -0.21 & 0.35 \\
\hline & Wuchang & 0.05 & 0.85 & 0.10 & 0.18 & -0.15 & 0.29 & 0.03 & 0.60 & -0.31 & 0.09 \\
\hline & Xinzhou & 0.21 & 0.52 & 0.08 & 0.44 & 0.10 & 0.59 & 0.06 & 0.44 & -0.33 & 0.18 \\
\hline Living area & $\begin{array}{l}\text { Central } \\
\text { city area }\end{array}$ & -0.13 & 0.03 & 0.01 & 0.68 & -0.04 & 0.27 & 0.01 & 0.68 & 0.02 & 0.71 \\
\hline
\end{tabular}


Table 7. Demographic characteristics of the participants' general perception toward air quality level.

\begin{tabular}{|c|c|c|c|c|c|}
\hline \multirow{2}{*}{\multicolumn{2}{|c|}{ Characteristics of the participants }} & \multicolumn{4}{|c|}{$\begin{array}{l}\text { What level of the } \mathrm{AQ} \text { in Wuhan do you } \\
\text { perceive in general? }\end{array}$} \\
\hline & & $\begin{array}{c}\text { I do not know } \\
(\%)\end{array}$ & $\begin{array}{l}\mathrm{Bad} \\
(\%)\end{array}$ & $\begin{array}{l}\text { Moderate } \\
(\%)\end{array}$ & $\begin{array}{c}\text { Good } \\
(\%)\end{array}$ \\
\hline \multirow{3}{*}{ Gender } & Female & 2 & 51 & 0 & 1 \\
\hline & Male & 0 & 45 & 1 & 0 \\
\hline & $<18$ & 0 & 16 & 0 & 0 \\
\hline \multirow{3}{*}{ Age } & $18-25$ & 2 & 45 & 1 & 0 \\
\hline & $25-45$ & 0 & 27 & 0 & 1 \\
\hline & $45-60$ & 0 & 9 & 0 & 0 \\
\hline \multirow{8}{*}{$\begin{array}{c}\text { Education } \\
\text { level }\end{array}$} & $>60$ & 0 & 0 & 0 & 0 \\
\hline & Middle school & 0 & 0 & 0 & 0 \\
\hline & High School & 0 & 6 & 0 & 0 \\
\hline & Junior college & 0 & 15 & 0 & 0 \\
\hline & Master & 2 & 59 & 1 & 1 \\
\hline & Bachelor & 0 & 13 & 0 & 0 \\
\hline & $\mathrm{PhD}$ & 0 & 3 & 0 & 0 \\
\hline & Enterprise & 1 & 20 & 0 & 1 \\
\hline \multirow{5}{*}{ Occupation } & Farmer & 0 & 0 & 0 & 0 \\
\hline & Freelancer & 0 & 5 & 0 & 0 \\
\hline & Public and governmental organization & 0 & 18 & 1 & 0 \\
\hline & Student & 0 & 51 & 0 & 0 \\
\hline & Other & 1 & 1 & 0 & 0 \\
\hline \multirow{13}{*}{$\begin{array}{l}\text { Living } \\
\text { district }\end{array}$} & Caidian & 0 & 1 & 0 & 0 \\
\hline & Dongxihu & 0 & 1 & 1 & 0 \\
\hline & Hannan & 0 & 0 & 0 & 0 \\
\hline & Hanyang & 0 & 3 & 2 & 0 \\
\hline & Hongshan & 0 & 23 & 8 & 0 \\
\hline & Huangpo & 0 & 0 & 0 & 0 \\
\hline & Jiangan & 0 & 4 & 2 & 0 \\
\hline & Jianghan & 0 & 4 & 2 & 0 \\
\hline & Jiangxia & 0 & 8 & 6 & 0 \\
\hline & Qiaokou & 0 & 3 & 1 & 0 \\
\hline & Qingshan & 0 & 2 & 1 & 0 \\
\hline & Wuchang & 0 & 15 & 8 & 0 \\
\hline & Xinzhou & 0 & 1 & 1 & 0 \\
\hline \multirow{2}{*}{ Living area } & Suburban area & 0 & 20 & 12 & 0 \\
\hline & Central city area & 0 & 45 & 1 & 21 \\
\hline
\end{tabular}


Table 8. Demographic characteristics of the participants' general knowledge about air pollution and its heath effect.

\begin{tabular}{|c|c|c|c|c|}
\hline \multirow{2}{*}{\multicolumn{2}{|c|}{ Characteristics of the participants }} & \multicolumn{3}{|c|}{$\begin{array}{c}\text { Do you know that air pollution can cause } \\
\text { negative health effects? }\end{array}$} \\
\hline & & Yes $(\%)$ & No (\%) & I do not know (\%) \\
\hline \multirow{3}{*}{ Gender } & Female & 47 & 1 & 1 \\
\hline & Male & 36 & 2 & 1 \\
\hline & $<18$ & 15 & 1 & 0 \\
\hline \multirow{4}{*}{ Age } & $18-25$ & 42 & 1 & 1 \\
\hline & $25-45$ & 19 & 0 & 0 \\
\hline & $45-60$ & 6 & 0 & 0 \\
\hline & $>60$ & 0 & 0 & 0 \\
\hline \multirow{6}{*}{$\begin{array}{c}\text { Education } \\
\text { level }\end{array}$} & Middle School & 0 & 0 & 0 \\
\hline & High School & 5 & 0 & 0 \\
\hline & Junior college & 13 & 0 & 0 \\
\hline & Bachelor & 54 & 2 & 1 \\
\hline & Master & 9 & 0 & 0 \\
\hline & $\mathrm{PhD}$ & 1 & 0 & 0 \\
\hline \multirow{6}{*}{ Occupation } & Enterprise & 20 & 0 & 0 \\
\hline & Farmer & 0 & 0 & 0 \\
\hline & Freelancer & 5 & 0 & 0 \\
\hline & Public and governmental organization & 7 & 0 & 0 \\
\hline & Student & 47 & 2 & 1 \\
\hline & Other & 2 & 0 & 0 \\
\hline \multirow{13}{*}{ Living district } & Caidian & 1 & 0 & 0 \\
\hline & Dongxihu & 2 & 0 & 0 \\
\hline & Hannan & 1 & 0 & 0 \\
\hline & Hanyang & 5 & 0 & 0 \\
\hline & Hongshan & 30 & 1 & 0 \\
\hline & Huangpo & 1 & 0 & 0 \\
\hline & Jiangan & 5 & 0 & 0 \\
\hline & Jianghan & 6 & 0 & 0 \\
\hline & Jiangxia & 14 & 0 & 0 \\
\hline & Qiaokou & 3 & 0 & 0 \\
\hline & Qingshan & 3 & 0 & 0 \\
\hline & Wuchang & 22 & 0 & 0 \\
\hline & Xinzhou & 2 & 0 & 0 \\
\hline \multirow{2}{*}{ Living area } & Suburban area & 31 & 1 & 0 \\
\hline & Central city area & 65 & 2 & 1 \\
\hline
\end{tabular}


Table 9. Demographic characteristics of the participants' general awareness for government actions.

\begin{tabular}{|c|c|c|c|c|}
\hline \multirow{2}{*}{\multicolumn{2}{|c|}{ Characteristics of the participants }} & \multicolumn{3}{|c|}{$\begin{array}{c}\text { Do you aware of any actions have been implemented in } \\
\text { Wuhan to reduce the air pollution? }\end{array}$} \\
\hline & & I do not care (\%) & I do not know (\%) & I know (\%) \\
\hline \multirow{2}{*}{ Gender } & Female & 1 & 32 & 15 \\
\hline & Male & 2 & 23 & 13 \\
\hline \multirow{5}{*}{ Age } & $<18$ & 0 & 11 & 4 \\
\hline & $18-25$ & 1 & 32 & 12 \\
\hline & $25-45$ & 0 & 9 & 10 \\
\hline & $45-60$ & 1 & 4 & 2 \\
\hline & $>60$ & 0 & 0 & 0 \\
\hline \multirow{6}{*}{ Education level } & Middle School & 0 & 0 & 0 \\
\hline & High School & 0 & 4 & 1 \\
\hline & Junior college & 1 & 9 & 4 \\
\hline & Bachelor & 2 & 35 & 19 \\
\hline & Master & 0 & 6 & 3 \\
\hline & $\mathrm{PhD}$ & 0 & 1 & 0 \\
\hline \multirow{6}{*}{ Occupation } & Enterprise & 1 & 11 & 9 \\
\hline & Farmer & 0 & 0 & 0 \\
\hline & Freelancer & 0 & 3 & 2 \\
\hline & $\begin{array}{c}\text { Public and governmental } \\
\text { organization }\end{array}$ & 0 & 4 & 4 \\
\hline & Student & 2 & 36 & 12 \\
\hline & Other & 0 & 1 & 1 \\
\hline \multirow[t]{13}{*}{ Living district } & Caidian & 1 & 0 & 0 \\
\hline & Dongxihu & 2 & 0 & 0 \\
\hline & Hannan & 0 & 1 & 0 \\
\hline & Hanyang & 0 & 6 & 0 \\
\hline & Hongshan & 0 & 31 & 0 \\
\hline & Huangpo & 0 & 1 & 0 \\
\hline & Jiangan & 0 & 6 & 0 \\
\hline & Jianghan & 0 & 6 & 0 \\
\hline & Jiangxia & 0 & 14 & 0 \\
\hline & Qiaokou & 0 & 0 & 4 \\
\hline & Qingshan & 0 & 0 & 3 \\
\hline & Wuchang & 0 & 0 & 23 \\
\hline & Xinzhou & 0 & 0 & 2 \\
\hline \multirow[t]{2}{*}{ Living area } & Suburban area & 4 & 29 & 0 \\
\hline & Central city area & 0 & 36 & 32 \\
\hline
\end{tabular}


Table 10. Demographic characteristics of the participants' willingness to change the behaviours.

\begin{tabular}{|c|c|c|c|}
\hline \multirow{2}{*}{$\begin{array}{c}\text { Characteristics } \\
\text { of the } \\
\text { participants }\end{array}$} & \multicolumn{3}{|c|}{$\begin{array}{l}\text { If the area you live requires the environmental contingency plans, and the } \\
\text { government requires you to reduce the private car driving time, do you accept? }\end{array}$} \\
\hline & \multirow{2}{*}{$\begin{array}{c}\text { I accept (\%) } \\
\text { Female }\end{array}$} & \multicolumn{2}{|c|}{ I do not accept (\%) } \\
\hline \multirow{2}{*}{ Gender } & & 47 & 1 \\
\hline & Male & 35 & 3 \\
\hline \multirow{6}{*}{ Age } & $<18$ & 14 & 1 \\
\hline & $18-25$ & 43 & 2 \\
\hline & $25-45$ & 19 & 1 \\
\hline & $45-60$ & 6 & 0 \\
\hline & $>60$ & 0 & 0 \\
\hline & Middle School & 0 & 0 \\
\hline \multirow{4}{*}{$\begin{array}{l}\text { Education } \\
\text { level }\end{array}$} & High School & 5 & 0 \\
\hline & Junior college & 13 & 1 \\
\hline & Master & 54 & 2 \\
\hline & Bachelor & 9 & 1 \\
\hline \multirow{8}{*}{ Occupation } & $\mathrm{PhD}$ & 1 & 0 \\
\hline & Enterprise & 20 & 1 \\
\hline & Farmer & 1 & 0 \\
\hline & Freelancer & 5 & 0 \\
\hline & Public and governmental organization & 7 & 0 \\
\hline & Student & 47 & 2 \\
\hline & Other & 2 & 0 \\
\hline & Caidian & 1 & 0 \\
\hline \multirow{11}{*}{ Living district } & Dongxihu & 2 & 0 \\
\hline & Hannan & 1 & 0 \\
\hline & Hanyang & 6 & 0 \\
\hline & Hongshan & 29 & 2 \\
\hline & Huangpo & 1 & 0 \\
\hline & Jiangan & 5 & 0 \\
\hline & Jianghan & 6 & 0 \\
\hline & Jiangxia & 14 & 1 \\
\hline & Qiaokou & 3 & 0 \\
\hline & Qingshan & 3 & 0 \\
\hline & Wuchang & 22 & 1 \\
\hline \multirow{3}{*}{ Living area } & Xinzhou & 2 & 0 \\
\hline & Suburban area & 31 & 1 \\
\hline & Central city area & 64 & 3 \\
\hline
\end{tabular}


Table 11. Demographic characteristics of the participants' air purifier needs at home.

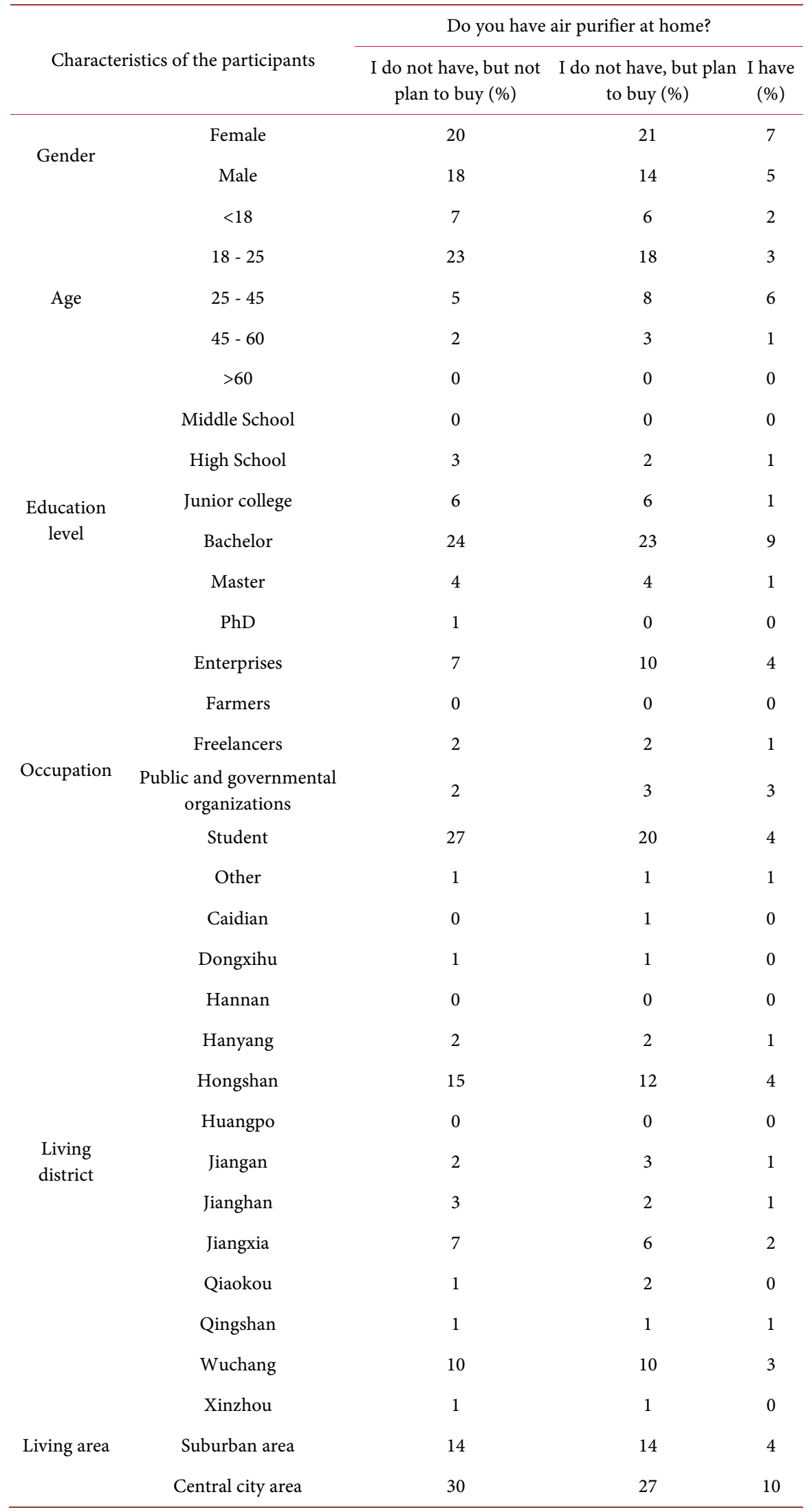


The participants of the Wuhan study were mainly composed of university students and workers either from enterprise or from public and governmental organizations and were comprised of mainly young people (91\% under 45 years). This represents the age structure of the general population in Wuhan (e.g., 0 - 14 (9.98\%); 15 - 64 (81.89\%); 65 (8.13\%)) [21]. Such results were also highlighted in a study of public perception in the Jin-Jing-Ji region in China [19].

Another finding was that more participants with college-level education or higher (94\%) took the survey than participants with a lower level education. Thisis contradicted by the education structure of the general population in the city (e.g., $14 \%$ with college-level or higher, $23 \%$ with high school education, $37 \%$ with middle school education, and $26 \%$ with only preliminary school education) [22]. Most participants lived in a central city area (58.6\%). This reflects the population distribution of the general population in Wuhan with $65 \%$ urban citizens [23]. Our results showed that most participants (83\%) had not been/are not involved in any air pollution related activities or work. This may indicate that the public awareness level is relatively high already.

The survey achieved its purpose in quantifying the participants' knowledge of air pollution and its effect on health in Wuhan. For example, nearly $68 \%$ of participants believed that $\mathrm{AQ}$ in Wuhan was bad, and this appeared to be consistent with the actual AQ situation in the city [24]. The official data on the annual average $\mathrm{PM}_{2.5}$ concentrations published by the Ministry of Environmental Protection (MEP) for 2013 in Wuhan was $88.7 \mathrm{ug} / \mathrm{m}^{3}$. This is 1.8 times higher than the national standard (which is $35 \mathrm{ug} / \mathrm{m}^{3}$ ) and the average daily $\mathrm{PM}_{2.5}$ level was 339 $\mathrm{ug} / \mathrm{m}^{3}$ [24]. However, $30 \%$ believed that $\mathrm{AQ}$ in Wuhan was moderate. Our results indicated that this difference between the participants' understanding with the actual AQ situation was the result of one factor, i.e., participants' living area, but not factors of the participants' gender, age, education level and occupation (Table 4). Participants living in the central city area ranked AQ worse when compared to participants living in the suburban area (Table 7). This is consistent with the results from other studies that showed that participants' perception of $A Q$ is related to proximity to the pollution sources [13].

Analysis of air pollution sources indicates that the majority of participants believed that bad AQ was due to motor vehicles, waste burning, roads and building construction, and industrial sources/manufacturing facilities. These results are generally consistent with findings from several recent reports [25] [26] [27]. Further, 64\% of participants were concerned about the AQI in Wuhan (Table 3 ), which is also consistent with finding from others AQ survey studies [10].

There is real time AQ information released by the HEMC, including the AQI, and this information was open to the public one year prior to the survey. However, only $22 \%$ of participants were aware of this. Consequently, we need to focus on future public health education programs to strengthen knowledge and understanding of $\mathrm{AQI}$, and where to find $\mathrm{AQI}$ information in order for it to be 
used by citizens for planning their daily activities.

$80 \%$ of participants indicated that they access Wuhan's AQ information via the Internet, followed by mobile App and TV (Table 3). These channels are vital to disseminate $\mathrm{AQ}$ information and could play a major role in informing citizens of environmental pollution in real-time. Similar AQ information access, including TV and Internet resources, have been identified in another survey on public attitudes and behaviors towards ambient air pollution and health in Ningbo, China [10].

The survey showed that most participants $(>96 \%)$ believed good AQ to be important, demonstrating that the public understands the association between $\mathrm{AQ}$ and human health which was also one of the major findings from the public perception of air pollution and health effects in Nanchang [2] [11] and Wuyuan [14], China [2]. In particular, $85 \%$ of participants indicated that they felt sick or uncomfortable when AQ was bad which aligns with the findings from another AQ survey in the Jin-Jing-Ji region where people felt air pollution affected their health [9]. Moreover, our results showed that farmers have less knowledge of air pollution and its health effects compared to students and people working in public and governmental organizations (Table 4). This may indicate that more awareness raising activities towards public with low education levels is acquired.

The Wuhan government has made several initiatives to improve AQ, such as upgrading and/or phasing out coal-powered boilers, prohibiting fireworks [10], converting the city bus and taxi fleets to liquefied petroleum gas (LPG) and compressed natural gas (CNG), and tightening requirements for PM caused by construction companies, etc. [28]. However, from our study, $65 \%$ of participants were not aware of such actions or did not believe that the government spent enough on environmental protection (Table 5). Our results showed that age, education and occupation were the main factors affecting participants' awareness of government actions (Table 4). Participants who were 25 - 45 years old were the most likely to have a high awareness level of government actions, while those participants with middle school and high school education and occupation as student had a low awareness level of government actions. This may indicate that policy level discussions mainly take place amongst policy makers, research and development institutes and others. However, the public, as a major stakeholder, is overlooked in the policy development strategy. This suggests a need for more effective mechanisms to disseminate air pollution and abatement measures to the public, as awareness is one of the key factors to help mitigate health risks associated with air pollution. The similar knowledge gaps, the need for improving the environmental awareness, and the calling for increasing government funding to improve AQ were also identified in others AQ survey studies in China [2] [9] [11] [13].

Citizens of Wuhan demonstrated an impressive willingness to change their behavior. In our study, $95 \%$ of participants indicated that they would modify their behavior (e.g., reduce their private car driving) if the government required 
it, in order to help improve AQ, etc.), and it seems more females and participants with master education are more willing to change their behavior (Table 10). Our results also indicate that participants in the age 25 - 45 working at public and governmental organizations have already higher number air purifiers at home, or were more willing to buy an air purifier, while high school students have quite lower number of air purifiers at home or were not willing to buy an air purifier (Table 11). Other similar studies indicated that the public has a strong health protection consciousness, e.g., taking protective measures indoors during haze weather, and wearing facemasks when going outside [10] [11]. These levels of public support will hopefully be leveraged by the decision-makers to help develop stricter regulations for AQ.

The participants suggested that there should be increased governmental funding in order to improve AQ. Other suggestions made by the participants included more focus on the control and reduction of air pollution from traffic and industry, reduction in waste burning, and increased public transportation. However, local government reports show that an increase of privately owned motor vehicles is the largest contributor of current air pollution in Wuhan [27].

Our study aimed at engaging heterogeneous population groups. However, the participants were composed mainly of students (50\%), enterprises (22\%) and administrative people (19\%). In addition, $79 \%$ of the participants have bachelors or higher education, $91 \%$ are under 45 years, and $69 \%$ are from central city area. To explore the general public perception and knowledge level on $A Q$, and for awareness raising, these types of limitations shall be further mitigated by covering more people of other groups (e.g., asthma and allergy patients, highly exposed people, residents of rural areas with lower levels of education, the elderly people, etc.) in any future study.

\section{Conclusions}

An innovative aspect of this survey was the exploration of participants' perceptions of AQ related issues. This was undertaken in order to develop recommendations for the provision of relevant, easy-to-understand AQ information and focused activity advice. As a result of the survey, it is clear that many people in Wuhan perceive air pollution to have a negative impact on human health. The survey responses indicated that in the public's opinion, vehicles and waste release from industry and domestic usage cause the majority of air pollution in the city.

Around $65 \%$ of survey participants felt that AQ was poor in Wuhan, while only $2 \%$ considered it good, with no serious threat imposed on the environment or on public health. This indicates that awareness levels of AQ related issues have increased dramatically, even though China does not have awareness or implementation strategies yet. Furthermore, this lack of any official strategy may explain why $51 \%$ of participants were unaware of the real-time AQ release system published by the government. Sources like electronic media and newspapers 
were the major mediums used by the participants to receive updates and notifications on air pollution.

The majority believed that respiratory disease is a major health risk as a result of air pollution. The study showed that the public supports governmental initiatives to improve $\mathrm{AQ}$ due to their concern that poor $\mathrm{AQ}$ can cause respiratory illnesses. A large number of participants (95\%) expressed their willingness to contribute to improving AQ in Wuhan.

However, organizing participation for improving $A Q$ at the community level remains a major challenge in Wuhan. And even though the government makes some effort to inform the citizens, the public is unaware of developments at the policy level, and feels that no enough information has been provided. In order to mitigate this, more effort on sharing information and raising awareness is now being made.

A majority of respondents expressed that they learned a lot about AQ issues via this survey and suggested that more surveys and public participation activities be performed in Wuhan for knowledge sharing and awareness raising. Several participants also stated that it is important that the government should make strong, sustainable initiatives, to improve quality of life. For the mitigation plan, respondents provided a number of possible solutions to mitigate the AQ issue. These were: 1) A mandatory legal framework should be enacted by the government prohibiting industries to pollute, and move those polluting industries outside the city; 2) Investment in research to introduce cleaner fuels and improve existing public transport systems; 3 ) To promote industries that employ renewable energy sources through tax incentives; 4) To introduce hybrid/electric vehicles to reduce emission levels, and 5) To increase support for air pollution and related topics in academia.

Initiatives such as this public perception survey are an important tool in gauging citizens' understanding of issues. However, they do much more than that. While providing data, they also help raise awareness and generate interest within the community, in this case leading to an action plan that may prove effective in air pollution mitigation.

\section{Acknowledgements}

The study presented here evolved from work undertaken in the project, $\mathrm{Hu}$ bei-AQ.info. Hubei-AQ.info is a project supported by the EU-China Environmental Governance Programme (EGP) and the Ministry of Environmental Protection, China (MEP). Special thanks to Li Liu at NILU (Norwegian Institute for Air Research) and two anonymous reviewers from the Journal of Environmental Protection for the suggestions and comments.

\section{References}

[1] WHO (2016) Ambient Air Pollution: A Global Assessment of Exposure and Burden of Disease. WHO Press, Geneva. 
[2] Lan, G., Yuan, Z., Maddock, J.E., Cook, A., Chu, Y., Pan, B., Tu, H., Fan, S., Liao, X. and Lu, Y. (2016) Public Perception of Air Pollution and Health Effects in Nanchang, China. Air Quality, Atmosphere and Health, 9, 951-959. https://doi.org/10.1007/s11869-016-0397-0

[3] Chitour, H.-L. (2013) Big Pharma in China-The Driving Forces behind Their Success-Qualitative Analysis. Chinese Studies, 2, 169-177. https://doi.org/10.4236/chnstd.2013.24028

[4] Yin, H., Xu, L. and Cai, Y. (2015) Monetary Valuation of PM10-Related Health Risks in Beijing China: The Necessity for PM10 Pollution Indemnity. International Journal of Environmental Research and Public Health, 12, 9967-9987. https://doi.org/10.3390/ijerph120809967

[5] The Ministry of Environmental Protection of the People's Republic of China (MEP) (2012) Ambient Air Quality Standards (GB 3095-2012). http://kjs.mep.gov.cn/hjbhbz/bzwb/dqhjbh/dqhjzlbz/201203/W02012041033023239 8521.pdf

[6] Liu, Q. (2016) 13th Five-Year Plan Is the First to Include PM2.5 Targets. https://www.chinadialogue.net/article/show/single/en/8696-13th-Five-Year-Plan-isthe-first-to-include-PM2-5-targets

[7] Quan, J., Zhang, Q., He, H., Liu, J., Huang, M. and Jin, H. (2011) Analysis of the Formation of Fog and Haze in North China Plain (NCP). Atmospheric Chemistry and Physics, 11, 8205-8214. https://doi.org/10.5194/acp-11-8205-2011

[8] Liu, H.-Y., Liu, H. and Hak, C. (2014) Hubei-AQ.info. Report on AQ Information towards the Public Based on the Outputs from the Questionnaires Based Survey. Norwegian Institute for Air Research, Kjeller.

[9] Yan, Y. (2016) Air Pollution in China: A Study of Public Perception. http://krex.k-state.edu/dspace/bitstream/handle/2097/32599/YihongYan2016.pdf?se quence $=5$ \&isAllowed $=\mathrm{y}$

[10] Yang, S. and Shi, L. (2017) Public Perception of Smog: A Case Study in Ningbo City, China. Journal of the Air \& Waste Management Association, 67, 219-230. https://doi.org/10.1080/10962247.2016.1229235

[11] Liao X., Tu, H., Maddock, J.E., Fan, S., Lan, G., Wu, Y., Yuan, Z.-K. and Lu, Y. (2015) Residents' Perception of Air Quality, Pollution Sources, and Air Pollution Control in Nanchang, China. Atmospheric Pollution Research 6, 835-841.

[12] Wang, R., Yang, Y., Chen, R., Kan, H., Wu, J., Wang, K., Maddock, J.E. and Lu, Y. (2015) Knowledge, Attitudes, and Practices (KAP) of the Relationship between Air Pollution and Children's Respiratory Health in Shanghai, China. International Journal of Environmental Research and Public Health, 12, 1834-1848. https://doi.org/10.3390/ijerph120201834

[13] Li, Z., Folmer, H. and Xue, J. (2016) Perception of Air Pollution in the Jinchuan Mining Area, China: A Structural Equation Modelling Approach. Journal of Environmental Research and Public Health, 13, 735. https://doi.org/10.3390/ijerph13070735

[14] Li, Y., Lin, F., Wu, Y., Pan, B., Lan, G., Fan, S., Yuan, Z. and Lu, Y. (2016) Survey Analysis of Occupational Impact on Perception of Air Pollution and Its Health Effect. Journal of Environment Pollution and Human Health, 4, 9-15.

[15] Statistics Bureau of Hubei Province (2012) Statistics Report of National Economic and Social Development of Wuhan. Statistics Bureau of Hubei Province, Wuhan.

[16] Environmental Protection Bureau of Wuhan (2012) Annual Report of Environ- 
mental Conditions of Wuhan. Environmental Protection Bureau of Wuhan, Wuhan.

[17] You, M. (2014) Addition of PM2.5 into the National Ambient Air Quality Standards of China and the Contribution to Air Pollution Control: The Case Study of Wuhan, China. The Scientific World Journal, 2014, 1-10. https://doi.org/10.1155/2014/603547

[18] Huang, H. and Wei, Y.D. (2014) Intra-Metropolitan Location of Foreign Direct Investment in Wuhan, China: Institution, Urban Structure, and Accessibility. Applied Geography, 47, 78-88.

[19] Wuhan Statistics Bureau (2010) The Sixth National Census in 2010-The Main Data Bulletin in Wuhan City (in Chinese). Wuhan Statistics Bureau, Wuhan.

[20] Sojump (2013) Questionnaire. https://www.sojump.com

[21] Ali, R. and Zhao, H. (2008) Wuhan, China and Pittsburgh, USA: Urban Environmental Health Past, Present, and Future. EcoHealth, 5, 159-166. https://doi.org/10.1007/s10393-008-0172-2

[22] Statistical Bureau of Hubei Province (2011) The Sixth National Population Census in Wuhan City in 2010-Main Data Bulletin. http://www.stats-hb.gov.cn/wzlm/tjgb/rkpcgb/fz/11028.htm

[23] Hubei Daily News (2013) Population Density Distribution in Wuhan District. http://www.ditiezu.com/forum.php?mod=viewthread\&tid=296878\&extra=\&orderty $\mathrm{pe}=2$

[24] R Development Core Team (2008) R: A Language and Environment for Statistical Computing. R Foundation for Statistical Computing, Vienna.

[25] Tan, M. (2014) Bad to Worse: Ranking 74 Chinese Cities by Air Pollution. http://www.greenpeace.org/eastasia/news/blog/bad-to-worse-ranking-74-chinese-ci ties-by-air/blog/48181

[26] Wang, S., Yu, S., Yan, R., Zhang, Q., Li, P., Wang, L., Liu, W. and Zheng, X. (2017) Characteristics and Origins of Air Pollutants in Wuhan, China, Based on Observations and Hybrid Receptor Models. Journal of the Air \& Waste Management Association, 67, 739-753. https://doi.org/10.1080/10962247.2016.1240724

[27] Guo, Y., Liu, F., Lu, Y., Mao, Z., Lu, H., Wu, Y., Chu, Y., Yu, L., Liu, Y., Ren, M., Li, N., Chen, X. and Xiang, H. (2016) Factors Affecting Parent's Perception on Air Quality-From the Individual to the Community Level. International Journal of Environmental Research and Public Health, 13, 493. https://doi.org/10.3390/ijerph13050493

[28] Song, J., Guang, W., Li, L. and Xiang, R. (2016) Assessment of Air Quality Status in Wuhan, China. Atmosphere, 7, 56. https://doi.org/10.3390/atmos7040056 
Submit or recommend next manuscript to SCIRP and we will provide best service for you:

Accepting pre-submission inquiries through Email, Facebook, LinkedIn, Twitter, etc. A wide selection of journals (inclusive of 9 subjects, more than 200 journals)

Providing 24-hour high-quality service

User-friendly online submission system

Fair and swift peer-review system

Efficient typesetting and proofreading procedure

Display of the result of downloads and visits, as well as the number of cited articles Maximum dissemination of your research work

Submit your manuscript at: http://papersubmission.scirp.org/

Or contact jep@scirp.org 